\title{
Phosphorous status and adsorption
} characteristics of acid soils from Cheha and Dinsho districts, southern highlands of Ethiopia

\author{
Bereket Ayenew ${ }^{1 *}$, Abi M. Tadesse ${ }^{2}$, Kibebew Kibret ${ }^{3}$ and Asmare Melese ${ }^{4}$
}

\begin{abstract}
Background: Though soils in the study areas are characterized by higher iron and aluminum oxides, and low available P contents, study on P adsorption characteristics is limited. The purpose of this experiment was to evaluate adsorption properties of selected soils and determine the standard phosphorous requirements of the soils. In this experiment, separately weighed $2 \mathrm{~g}$ soil samples were equilibrated in $50 \mathrm{ml}$ of $0.01 \mathrm{M} \mathrm{CaCl}_{2}$ solution containing $\mathrm{KH}_{2} \mathrm{PO}_{4}$ at rates of $0,1,2.0,4.0,8.0,16.0,24.0$, and $32.0 \mathrm{mg} \mathrm{PL}^{-1}$.

Results: The Freundlich model was found to be the best model for the description of the $\mathrm{P}$ adsorption characteristics of the soils. The Freundlich coefficient $K_{f}$ ranged from 123.32 to $315.31 \mathrm{mg} \mathrm{P} \mathrm{kg}^{-1}$. The Goha-1 soil had the highest $K_{f}$ (315.31 $\mathrm{mg} \mathrm{P} \mathrm{kg}^{-1}$ ) as Ketasire had lowest $K_{f}\left(123.32 \mathrm{mg} \mathrm{P} \mathrm{kg}^{-1}\right)$ values. The value of $S P R_{f}$ was ranged from 50.50 to $154.02 \mathrm{mg} \mathrm{P} \mathrm{kg}^{-1}$ for soils of the study area. Highly significant $(P \leq 0.01)$ correlation was observed between the Freundlich adsorption parameters and soil physicochemical properties.

Conclusion: The standard $\mathrm{P}$ requirement of the studied soils was higher than the blanket $\mathrm{P}$ fertilizer rate recommendations in Ethiopia. Lack of inadequate knowledge about internal and external P requirement of each crop might have decreased yield in the study areas as it could have resulted in under-application of fertilizer P. The presence of high correlation between the adsorption parameters and the soil properties suggested the indices' prominent role in explaining $\mathrm{P}$ adsorption characteristics of the soils. Since higher dose of $\mathrm{P}$ is required by soils in the study area because of fixation, alternative $P$ management strategies is needed to reduce $P$ adsorption and enhance $P$ availability.
\end{abstract}

Keywords: Fertilizer, Freundlich model, Isotherm, Oxyhydoxides, Phosphorous requirement

\section{Background}

Phosphorus $(\mathrm{P})$ in soils is important because adequate availability of this nutrient among other nutrients is required for plant growth and crop production. However, in acidic soils, leaching of elements such as $\mathrm{Ca}, \mathrm{Mg}$, $\mathrm{K}$ and $\mathrm{Na}$, silicates and carbonates, and transformations of $\mathrm{Fe}$ and $\mathrm{Al}$ into oxides or oxyhydroxides creates new functional groups for P adsorption (Jesse et al. 2016). Phosphorus $(\mathrm{P})$ deficiency is particularly widespread in

\footnotetext{
*Correspondence: bersofsam12@gmail.com

1 School of Natural Sciences, Department of Chemistry, Madda Walabu University, Bale-Robe, Ethiopia

Full list of author information is available at the end of the article
}

rain-fed upland farming systems throughout the tropics and remains a major plant nutrient constraint (Asmare et al. 2015). Similar to the other agricultural soils of the tropics Ethiopian soils are generally low in $\mathrm{P}$ (Mamo and Haque 1987) and hence $P$ is one of the limiting elements in crop production in the highlands of the country. Therefore, $\mathrm{P}$ application has become an essential part of crop production systems in order to provide adequate food and fiber for human consumption (Jalali 2007).

Phosphorous reacts readily with metallic species and in highly weathered acidic soils, $\mathrm{Fe}$ and $\mathrm{Al}$ oxyhydroxides are the dominant species with which adsorption of $P$ occurs principally via the formation of an inner-sphere 
complex between orthophosphate anions and amorphous oxides [ $\mathrm{Fe}_{\text {ox }}$ and $\mathrm{Al}_{\text {ox }}$ (Tan 2000; Sims and Pierzynski 2005; Ahmed et al. 2008; Rayment and Lyons 2011)]. These short range crystalline oxyhydroxides (amorphous) are well known to affect P sorption in soils (Janardhanan and Daroup 2010). Phosphorus adsorption depends on the nature and quality of sites available on the mineral surfaces and is therefore affected by high clay contents (Bahia et al. 1983). Studies also revealed that (Bedin et al. 2003; Moreira et al. 2006) the presence of large proportions of sesquioxides on clays, $\mathrm{pH}$, exchangeable aluminum and organic matter influence phosphate adsorption and precipitation with iron and aluminum.

The extent of $\mathrm{P}$ adsorption and availability greatly varies from soil to soil owing to their differences in physicochemical properties (Muindi et al. 2015) and management (Moazed et al. 2010). Thus, understanding the P-sorption characteristics of soils are important for designing appropriate management strategies and predicting fertilizer requirements that are needed to be applied (Zhang et al. 2005). Most of the current management strategies rely on measuring $P$ availability by leaching the soil with an extractant (Hansen and Strawn 2003). However, sorption reactions and phosphorous buffer capacity (PBC) of soils play an important role in both agronomic and environmental $\mathrm{P}$ management aspects. Sorption isotherms are much used to characterize the retention of $\mathrm{P}$ and the PBC of soil (Yli-halla et al. 2002).

Phosphorus availability to plants is mainly ruled by three factors: (i) the concentration of $\mathrm{P}$ in the soil solution ('intensity' factor, I), (ii) the amount of $\mathrm{P}$ in the solid phase that can be easily made available to plants ('quantity' factor, Q), and (iii) the capacity of soil to keep the P concentration in soil solution sufficiently high ( $\mathrm{P}$ buffer capacity, PBC) (Sánchez-Alcalá et al. 2014). The capacity of the soil to adsorb $\mathrm{P}$ greatly influences plant responses to applied P fertilizers and the calibration of soil tests for P (Amrani et al. 1999). Therefore, knowledge of the ability of the soil to adsorb $\mathrm{P}$ fertilizer is required to provide an accurate estimate on the $P$ fertilizer requirements of soils (Jalali 2007). This could be obtained by determining the amount of $\mathrm{P}$ adsorbed by soils at a concentration of phosphorus in solution known to be non-limiting to plant growth (Henry and Smith 2003).

Although most highland soils are characterized by soil acidity and high P fixation capacity due to intensive weathering and leaching attributed to high rainfall conditions (Desta 2015), little is known about soil P adsorption capacity and P fertilizer requirements of soils in Ethiopian highlands. Moreover, factors affecting the adsorption capacity of the soils and appropriate amount of $\mathrm{P}$ fertilizer required by the soils of the study area have not yet been investigated. Thus, the objective of the present work was to evaluate the $\mathrm{P}$ adsorption characteristics of soils and estimate the adequate amount of fertilizer $\mathrm{P}$ required by the soils and relate the coefficients of the adsorption models to the soil chemical properties.

\section{Methods \\ Description of the study area}

The study was conducted in Ethiopian highlands of Dinsho district in Bale zone and Cheha district in Gurage zone, Ethiopia (Fig. 1). Dinsho district lies between $6^{\circ} 58^{\prime} 40^{\prime \prime}$ and $7^{\circ} 20^{\prime} 0^{\prime \prime} \mathrm{N}$, and $39^{\circ} 44^{\prime} 0^{\prime \prime}$ and $40^{\circ} 26^{\prime} 40^{\prime \prime} \mathrm{E}$. Physiographically, most of the land area of the district is situated above $2000 \mathrm{~m}$ above sea level (masl). The district is classified into three agro-climatic zones: highlands (2300-2600 masl), midlands (1500-2300), and lowlands (1200-1500). The district has a bimodal rainfall distribution with mean annual rainfall of about $1150 \mathrm{~mm}$. The maximum and minimum mean annual temperatures of the District are 17.5 and $6{ }^{\circ} \mathrm{C}$, respectively. Wheat and barley are some of the major cereal crops grown in the area. The major reference soil groups in the district are Pellic Vertisols, Eutric Cambisols, Eutric Nitosols (now Nitisols), and Chromic Luvisols (FAO 1984).

Cheha district is situated between $8^{\circ} 32^{\prime} 0^{\prime \prime}$ and $8^{\circ} 20^{\prime} 0^{\prime \prime}$ $\mathrm{N}$, and $37^{\circ} 41^{\prime} 20^{\prime \prime}$ and $38^{\circ} 2^{\prime} 40^{\prime \prime} \mathrm{E}$, at an elevation that ranges from 900 to 2812 masl. EIAR (2011) classified the area into three agro-ecological zones i.e. highlands (2300-3200 masl), midlands (1500-2300 masl), and lowlands (500-1500 masl) based on the bimodal rain fall system. The 10 years mean annual rainfall of the district is about $1268 \mathrm{~mm}$. The mean annual maximum and minimum temperatures are 24.97 and $10.69^{\circ} \mathrm{C}$, respectively. The dominant soil types are Eutric Nitosols, Leptosols, and Pellic Vertisols (FAO 1984).

\section{Site selection, soil sampling, and soil analysis}

A preliminary soil survey and field observation was made using topographic map $(1: 50,000)$ of the study area. Soil pH (potentiometer), altitude (GPS), and slope (clinometer) were used as criteria for selection of soil sampling sites. Fifteen (15) sub-samples were collected from each sampling site to make one composite sample. Accordingly, twelve composite soil samples $(0-15 \mathrm{~cm})$, seven from Cheha district (Goha 1, Goha 2, Goha 3, Aftir, Abret, Kechot, and Moche), and five from Dinsho district (Doyomarufa 1, Doyomarufa 2, Tulu, Weni, and Ketasire) having $\mathrm{pH}$ values of less than 5.5 were obtained within an altitudinal range of 2000-3000 masl and slope less than $8 \%$ (Table 1). Soil pH was measured at field condition using portable $\mathrm{pH}$ meter to select soils having a $\mathrm{pH}$ of less than 5.5 . The soil samples were put in plastic bag, tagged, and transported to laboratory for analysis during the 2014/15. Consequently, adequate 


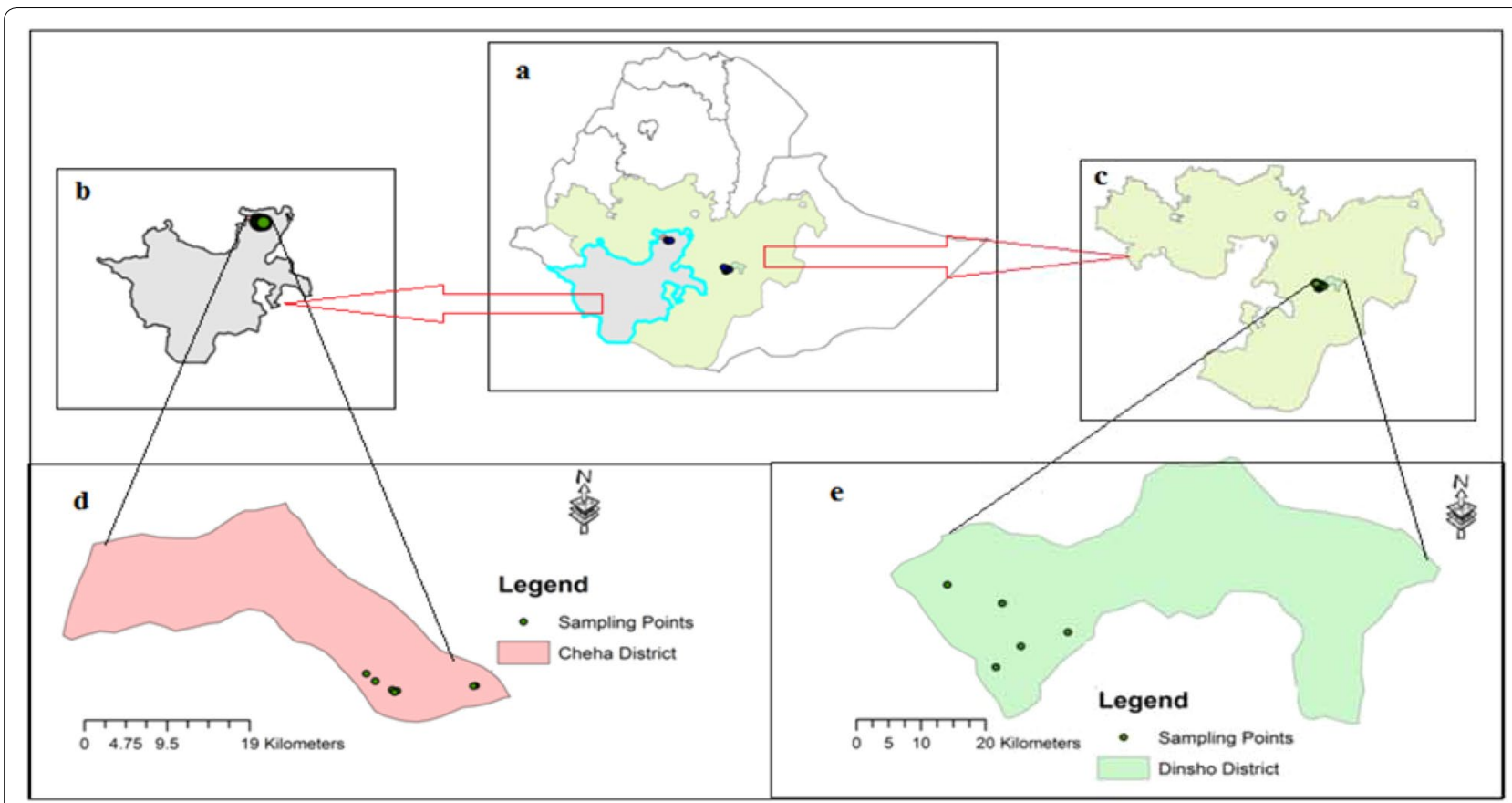

Fig. 1 Location Map of the Study Areas, a Oromia and SNNP regions in Ethiopia, b Cheha district in SNNP region, c Dinsho district in Oromia region, d Cheha district, e Dinsho district

Table 1 Sampling locations and site description

\begin{tabular}{lllll}
\hline $\begin{array}{l}\text { Sampling } \\
\text { Sites }\end{array}$ & $\begin{array}{l}\text { Longitude } \\
\text { (E) }\end{array}$ & Latitude (N) & $\begin{array}{l}\text { Altitude } \\
\text { (masl) }\end{array}$ & Slope (\%) \\
\hline SC1 & $037^{\circ} 93^{\prime} 891^{\prime \prime}$ & $08^{\circ} 033^{\prime} 45^{\prime \prime}$ & 2426 & 4 \\
SC2 & $037^{\circ} 94^{\prime} 389^{\prime \prime}$ & $08^{\circ} 032^{\prime} 35^{\prime \prime}$ & 2508 & 3 \\
SC3 & $037^{\circ} 94^{\prime} 134^{\prime \prime}$ & $08^{\circ} 030^{\prime} 78^{\prime \prime}$ & 2498 & 2 \\
SC4 & $037^{\circ} 91^{\prime} 180^{\prime \prime}$ & $08^{\circ} 052^{\prime} 36^{\prime \prime}$ & 2302 & 5 \\
SC5 & $037^{\circ} 92^{\prime} 114^{\prime \prime}$ & $08^{\circ} 043^{\prime} 58^{\prime \prime}$ & 2401 & 3 \\
SC6 & $038^{\circ} 02^{\prime} 572^{\prime \prime}$ & $08^{\circ} 038^{\prime} 63^{\prime \prime}$ & 2603 & 5 \\
SC7 & $038^{\circ} 02^{\prime} 377^{\prime \prime}$ & $08^{\circ} 038^{\prime} 23^{\prime \prime}$ & 2563 & 5 \\
SD1 & $039^{\circ} 51^{\prime} 934^{\prime \prime}$ & $07^{\circ} 075^{\prime} 65^{\prime \prime}$ & 2819 & 4 \\
SD2 & $039^{\circ} 51^{\prime} 900^{\prime \prime}$ & $07^{\circ} 072^{\prime} 28^{\prime \prime}$ & 2832 & 5 \\
SD3 & $039^{\circ} 52^{\prime} 387^{\prime \prime}$ & $07^{\circ} 066^{\prime} 39^{\prime \prime}$ & 2790 & 3 \\
SD4 & $039^{\circ} 52^{\prime} 450^{\prime \prime}$ & $07^{\circ} 071^{\prime} 01^{\prime \prime}$ & 2768 & 2 \\
SD5 & $039^{\circ} 52^{\prime} 714^{\prime \prime}$ & $07^{\circ} 080^{\prime} 40^{\prime \prime}$ & 2719 & 5 \\
\hline
\end{tabular}

SC1 Goha 1, SC2 Goha 2, SC3 Goha 3, SC4 Aftir, SC5 Abret, SC6 Kechot, SC7 Moche, SD1 Doyomarufa 1, SD2 Doyomarufa 2, SD3 Tulu, SD4 Weni, SD5 Ketasire

(about $1 \mathrm{~kg}$ ) amount of composited soil samples were air dried and ground to pass through a $2 \mathrm{~mm}$ sieve for analysis of selected soil chemical and physical properties except organic carbon and total nitrogen in which case the samples were passed through a $0.5 \mathrm{~mm}$ sieve.
Analysis of soil physical and chemical properties

Soil particle size distribution was analyzed by the Bouyoucus hydrometer method (Day 1965). Soil bulk density was measured from three undisturbed soil samples collected using a core sampler following the procedure described by Jamison et al. (1950). Soil pH measured potentiometrically in $\mathrm{H}_{2} \mathrm{O}$ and $1 \mathrm{M} \mathrm{KCl}$ solution at the ratio of 1:2.5 for soil: water and soil: $\mathrm{KCl}$ solutions using a combined glass electrode $\mathrm{pH}$ meter (Van Reeuwijk 1992). Cation exchange capacity (CEC) of the soils was determined by making use of the method suggested by Lavkulich (1981). Exchangeable acidity was determined by saturating the soil samples with $1 \mathrm{M} \mathrm{KCl}$ solution and titrating with $0.02 \mathrm{M} \mathrm{NaOH}$ as described by Rowell (1994). Soil organic carbon was determined by the dichromate oxidation method as described by Walkley and Black (1934). Available P was determined as Mehlich-3 $\mathrm{P}$ by shaking the soil samples with an extracting solution of $0.2 \mathrm{M} \mathrm{CH}_{3} \mathrm{COOH}+0.25 \mathrm{M}$ $\mathrm{NH}_{4} \mathrm{NO}_{3}+0.015 \mathrm{M} \mathrm{NH}_{4} \mathrm{~F}+0.013 \mathrm{M} \mathrm{HNO}_{3}+0.001 \mathrm{M}$ EDTA for $5 \mathrm{~min}$ (Mehlich 1984) and total soil P was determined using the method stated by Olsen and Sommers (1982).

The $\mathrm{P}$ fractions were successively extracted with $1 \mathrm{M}$ $\mathrm{NH}_{4} \mathrm{Cl}$ (available $\mathrm{Pi}$ ), $0.5 \mathrm{NaHCO}_{3}$ (labile $\mathrm{P}_{\mathrm{i}}$ and $\mathrm{Po}$ adsorbed on the soil surface), $0.1 \mathrm{M} \mathrm{NaOH}$ (moderately labile Pi and Po held more strongly by chemisorption to surfaces of $\mathrm{Al}$ and $\mathrm{Fe}$ oxides), Sonicate $+0.1 \mathrm{M} \mathrm{NaOH}$ 
( $\mathrm{Pi}$ and $\mathrm{Po}$ adsorbed within surfaces of $\mathrm{Al}$ and $\mathrm{Fe}$ oxides of soil aggregates-occluded $\mathrm{P}), 1 \mathrm{M} \mathrm{HCl}$ ( $\mathrm{P}$ associated to $\mathrm{Ca}$, derived from primary mineral-apatite) and a mixture of $\mathrm{HNO}_{3}$ and $\mathrm{HClO}_{4}$ (residual P-non-labile, stable Po forms and relatively insoluble Pi forms) as described by Hedley et al. (1982) and modified by Chen et al. (2000). The oxalate extractable $\mathrm{P}, \mathrm{Al}$ and $\mathrm{Fe}\left(\mathrm{P}_{\mathrm{ox}}, \mathrm{Al}_{\mathrm{ox}}\right.$ and $\mathrm{Fe}_{\mathrm{ox}}$ ) were determined with $0.05 \mathrm{M}$ ammonium oxalate $\left(\left(\mathrm{NH}_{4}\right)_{2} \mathrm{C}_{2} \mathrm{O}_{4} \cdot 2 \mathrm{H}_{2} \mathrm{O}, \mathrm{pH}\right.$ 3.3) for $2 \mathrm{~h}$ in the dark (Mckeague and Day 1966). Citrate bicarbonate dithioniteextractable $\mathrm{Fe}$ and $\mathrm{Al}\left(\mathrm{Fe}_{\mathrm{d}}\right.$ and $\left.\mathrm{Al}_{\mathrm{d}}\right)$ were determined by the method of Mehra and Jackson (1960). The degree of $P$ saturation (DPS) was determined as the percentage of the ratio of the different forms of $\mathrm{P}$ to the oxalate extractable $\mathrm{Al}$ and $\mathrm{Fe}\left(\mathrm{Al}_{\mathrm{ox}}\right.$ and $\left.\mathrm{Fe}_{\mathrm{ox}}\right)$ as follows (Van der Zee et al. 1988).

\section{Phosphorous adsorption characteristic study}

In view of the results of several studies on adsorption characteristics of acidic soils of Ethiopia (Birru et al. 2003; Asmare 2014; Zinabu et al. 2015) and P adsorption kinetics of the studied soils (Bereket 2017) (unpublished) it was decided to use low initial $\mathrm{P}$ concentrations for adsorption experiments. Data for plotting P adsorption isotherms were obtained by equilibrating triplicate samples of $2 \mathrm{~g}$ of each soil. Following the procedure of Fox and Kamprath (1970), separate air-dried ground soil was equilibrated in $50 \mathrm{ml}$ of $0.01 \mathrm{M} \mathrm{CaCl}_{2}$ supporting electrolytes containing $\mathrm{KH}_{2} \mathrm{PO}_{4}$ at rates of $0.0,1.0,2.0,4.0$, 8.0, 16.0, 24.0, and $32.0 \mathrm{mg} \mathrm{P} \mathrm{L}^{-1}$. Three drops of toluene were added to each container to inhibit microbial activity. Three similar sets of containers for each soil were prepared and equilibration was carried out in $50 \mathrm{ml}$ tube for $24 \mathrm{~h}$ at $25^{\circ} \mathrm{C}$. Each tube was covered with stopper to check the water losses through evaporation. Immediately after equilibration, the tubes were centrifuged and the supernatant solution was filtered through Wattman 42 filter paper and $\mathrm{P}$ content of the supernatant was determined using the ascorbic acid molybdenum blue color method (Watanabe and Olsen 1965). The quantities of $\mathrm{P}$ adsorbed by the soil were calculated from the difference between the initially applied $\mathrm{P}$ and the equilibrium soil solution P concentration (Yli-Halla et al. 2002). The $P$ adsorption properties of the soil samples were studied with the $\mathrm{Q} / \mathrm{Ce}(\mathrm{Q}=$ adsorbed $\mathrm{P}$ and $\mathrm{Ce}=$ equilibrium $\mathrm{P}$ concentration) plot technique. Meanwhile, soil external $P$ requirements were determined by substituting the desired $\mathrm{P}$ concentration into the fitted equations (Dodor and Oya 2000). The adsorption data were fitted to the Langmuir and Freundlich models and coefficients of the equations which best describe the sorption data has been used for a correlation study. The linear form of the Langmuir model could be written as:

$$
1 / \mathrm{Q}=1 / \mathrm{Q}_{\max }+1 /\left(\mathrm{KL}_{\max } \mathrm{Ce}\right)
$$

where $\mathrm{Q}=$ amount of $\mathrm{P}$ adsorbed $\left(\mathrm{mg} \mathrm{P} \quad \mathrm{Kg}^{-1}\right)$, $\mathrm{Q}_{\max }=$ maximum amount of $\mathrm{P}$ adsorbed $\left(\mathrm{mg} \mathrm{P} \mathrm{Kg}^{-1}\right.$ soil), $\mathrm{Ce}=$ equilibrium $\mathrm{P}$ concentration $\left(\mathrm{mg} \mathrm{P} \mathrm{L}^{-1}\right), \mathrm{K}_{\mathrm{L}}=$ affinity coefficient between phosphate ions and the surface of soil particles, which is related to the bonding energy $\left(\mathrm{L} \mathrm{mg}^{-1}\right)$.

The linear form of the Freundlich model can be written as:

$$
\log \mathrm{Q}=\log \mathrm{Kf}+\mathrm{N} \log \mathrm{Ce}
$$

where $\mathrm{Q}=$ amount of $\mathrm{P}$ adsorbed $\left(\mathrm{mg} \mathrm{P} \mathrm{kg}^{-1}\right), \mathrm{Ce}=$ equilibrium solution $\mathrm{P}$ concentration $\left(\mathrm{mg} \mathrm{P} \mathrm{L}^{-1}\right)$ and $\mathrm{K}_{\mathrm{f}}$ and $\mathrm{N}$ are fitting parameters (buffer power). The $\mathrm{K}_{\mathrm{f}}$ values represents the amount of $\mathrm{P}$ adsorbed $\left(\mathrm{mg} \mathrm{kg}^{-1}\right)$ at unit equilibrium concentration.

From the adsorption isotherms, the standard $\mathrm{P}$ requirement (SPR) $\left(\mathrm{mg} \mathrm{kg}^{-1}\right)$ of the soil was determined. The SPR is the amount of $\mathrm{P}$ required to maintain an equilibrium concentration of $0.2 \mathrm{mg} \mathrm{P} \mathrm{L}{ }^{-1}$ in soil solution which has been shown to be a threshold for many crops. The PBC was derived by the first derivative of $\mathrm{Q}$ to $\mathrm{Ce}$, from the non-linear Q-Ce curve (Ehlert et al. 2003) i.e. the slope of the curve at $0.2 \mathrm{mg} \mathrm{P} \mathrm{L}^{-1}$ concentration of $\mathrm{P}$ (Morel et al. 2000).

The dQ/dCe of the Freundlich model is computed as:

$$
\mathrm{dq} / \mathrm{dCe}=\mathrm{K}_{\mathrm{f}} \times \mathrm{N} \times \mathrm{Ce}^{\mathrm{N}-1}
$$

Similarly, the $\mathrm{dQ} / \mathrm{dCe}$ of the Langmuir model is as follows:

$$
\mathrm{dq} / \mathrm{dC}=\mathrm{Q}_{\max } \times \mathrm{K}_{\mathrm{L}} /\left(1+\mathrm{C}_{\mathrm{e}} \times \mathrm{K}_{\mathrm{L}}\right)^{2}
$$

\section{Statistical analysis}

The experimental data were statistically analyzed using SAS version 9.00 (SAS 2004). The fit of each adsorption model was evaluated by the determination coefficient $\left(\mathrm{R}^{2}\right)$ and root mean square error (RMSE) at a confidence level of $95 \%$. Furthermore, the coefficients of the Freundlich model were correlated with the chemical properties of the studied soils.

\section{Results and discussion}

\section{Physicochemical properties of the studied soils}

The textural class of studied soils was predominantly clayey. In this regard, the clay content of the studied soils ranged from 36.6 to $49.8 \%$ and the highest clay content was recorded from SC3 soil, while the lowest was obtained from SD3 soil. The variation in percent clay among the soils studied could be attributed to land use history, the intensity of cultivation. On this subject Onweremadu et al. (2007) noted slight temporal textural differences in arable soils resulting from continuous 


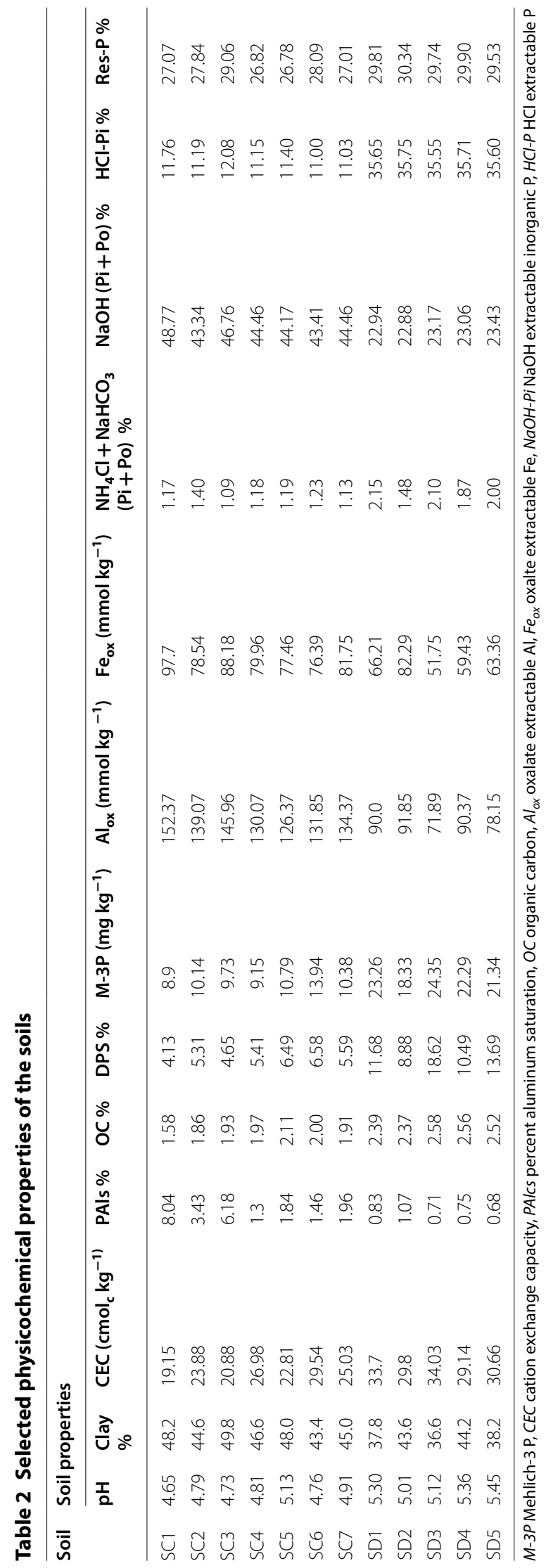


cultivation. The $\mathrm{pH}\left(\mathrm{H}_{2} \mathrm{O}\right)$ value of the soils varied between 4.65 and 5.45. Based on the rating suggested by Jones (2003), very strongly acidic soils accounted for $58 \%$, while $42 \%$ of the studied soils could be categorized as strongly acidic suggesting the presence of substantial quantities of exchangeable hydrogen and aluminum ions which are associated with acidity (Table 2).

The cation exchange capacity of the studied soils ranged from 21.15 to $36.03 \mathrm{cmol}_{\mathrm{c}} \mathrm{kg}^{-1}$. According to Hazelton and Murphy (2007) the CEC of the soils were in the range of moderate to high values. The variation in $\mathrm{CEC}$ among the soils might be due to the differences in $\mathrm{OM}$ content, clay mineral content and $\mathrm{pH}$ range of the soils (Table 2). In agreement with the current study Peinemann et al. (2002) reported that clay and organic matter are the main sources of CEC and the more clay and organic matter (humus) a soil contains, the higher its CEC. The exchangeable acidity and exchangeable $\mathrm{Al}$ of the studied soils were found to be in the range of 0.562.61 cmolc $\mathrm{kg}^{-1}$ and $0.21-1.54$ cmolc kg$^{-1}$, respectively. The variability in exchangeable $\mathrm{Al}$ in soils was probably due to the different soil types and other soil chemical properties, such as $\mathrm{pH}$, the organic matter content and CEC of the soils (Al Baquy et al. 2017).

The percentage of organic carbon in soils in the study area was ranged from 1.58 to $2.58 \%$ (Table 2). In general, as per the rating developed by Hazelton and Murphy (2007) OC content of soils of the study area were ranged from moderate with average structural condition and stability $(1.00-1.80 \%)$ to high $(1.80-3.00 \%)$ with a good structural condition and stability. The variation in percent organic carbon in soils of the study area could be attributed to the management practices. Many studies confirm that carbon retention in soil is influenced by crop management systems, such as crop rotation (Saljnikov-Karbozova et al. 2004), tillage (Saljnikov et al. 2009), residue management (Rasmussen et al. 1980) and fertilization and fertility (Saljnikov et al. 2005).

The amount of $\mathrm{P}$ extracted with Mehlich-3 ranged from 8.90 to $25.75 \mathrm{mg} \mathrm{kg}^{-1}$. However, there was a considerable variation among soils of the districts in terms of the available P. As per the rating established by EthioSIS (2014), Mehlich-3 extractable P contents of studied soils could be qualified as very low $\left(0-15 \mathrm{mg} \mathrm{kg}^{-1}\right)$ and low (15-30 $\left.\mathrm{mg} \mathrm{kg}^{-1}\right)$ for soils. Soils of the study area were appeared to have different concentrations of dithionitecitrate-bicarbonate (DCB) and oxalate extractable $\mathrm{Fe}$, $\mathrm{Al}$, and $\mathrm{P}$. Consequently, $\mathrm{Al}_{\mathrm{ox}}$ contents of the soils varied between 78.148 and $147.37 \mathrm{mmol} \mathrm{kg}{ }^{-1} ; \mathrm{Fe}_{\mathrm{ox}}, 73.75$ and $174.69 \mathrm{mmol} \mathrm{kg}^{-1}$; Pox, 5.51 and $12.29 \mathrm{mmol} \mathrm{kg}{ }^{-1}$; DPS, 4.13 and $18.62 \%$. In view of the cut off point for loss of $P$ due to runoff (Ige et al. 2005) all the studied soils, showed DPS values less than $20 \%$ indicating no risk of P loss from soil. These low values might be attributed to the higher adsorption capacity of these soils for applied P fertilizer.

The relative abundances of $\mathrm{P}$ forms in the studied soils were in the following order: Res- $\mathrm{P}>\mathrm{NaOH}-\mathrm{Po}>\mathrm{NaOH}-$ $\mathrm{Pi}>\mathrm{HCl}-\mathrm{P}>(\mathrm{NaOH}-\mathrm{Pi}) \mathrm{sn}>(\mathrm{NaOH}-\mathrm{Po}) \mathrm{sn}>\mathrm{NaHCO}_{3}-$ $\mathrm{Po}>\mathrm{NaHCO}_{3}-\mathrm{Pi}>\mathrm{NH}_{4} \mathrm{Cl}-\mathrm{P}$ in soils from Cheha District and $\mathrm{HCl}-\mathrm{P}>\mathrm{Res}-\mathrm{P}>\mathrm{NaOH}-\mathrm{Po}>\mathrm{NaOH}-\mathrm{Pi}>(\mathrm{NaOH}-\mathrm{Po})$ sn $>(\mathrm{NaOH}-\mathrm{Pi}) \mathrm{sn}>\mathrm{NaHCO}_{3}-\mathrm{Po}>\mathrm{NaHCO}_{3}-\mathrm{Pi}>\mathrm{NH}_{4} \mathrm{Cl}-\mathrm{P}$ for soils of Dinsho district. The labile $\mathrm{P}\left(\mathrm{Pi}\right.$ in $\mathrm{NH}_{4} \mathrm{Cl}+\mathrm{Pi}$ and $\mathrm{Po}$ in $\mathrm{NaHCO}_{3}$ ) varied between 1.09 and $2.15 \%$ suggesting plant growth could be affected due to the presence of low biologically available $\mathrm{P}$ forms (Kiflu et al. 2017). The moderately labile $\mathrm{P}(\mathrm{Pi}+\mathrm{Po}$ in $\mathrm{NaOH})$ called the $\mathrm{Fe}-\mathrm{Al}$ associated $\mathrm{P}$ was varied between 22.88 and $48.77 \%$ and appeared to be very high compared to other fractions. The relatively higher abundance of $\mathrm{Al}$ and $\mathrm{Fe}$ bound $\mathrm{P}$ could be as a result of the presence of variable $\mathrm{Al}$ and Fe contents in soils at various stages of relative development and their reaction with soil P (Kiflu et al. 2017). On the other hand the $\mathrm{P}$ associated to $\mathrm{Ca}(\mathrm{HCl}-\mathrm{Pi})$ varied between 11.00 and $35.75 \%$ which could be attributed to the difference in Ca contents of the studied soils and the residual-P varied between 26.78 and 30.34\% (Table 2).

\section{Phosphorous adsorption characteristics Phosphorous adsorption isotherms}

The preliminary investigation we carried out on phosphorous adsorption kinetics exhibited a period of $24 \mathrm{~h}$ for maximum $\mathrm{P}$ adsorption. Furthermore, the kinetic models also pointed out that the best linear regression was observed at lower initial $\mathrm{P}$ concentrations. Therefore, Phosphate adsorption isotherms of the studied soils were determined by plotting the equilibrium concentration of phosphate $(\mathrm{Ce})$ against the amount of phosphate adsorbed (Q) which was resulted from 24 h equilibration period.

A graphical illustration of the adsorption isotherms of the studied soils with different curves followed a smooth plateau pattern depicting variation in data set, where shape of isotherms appeared to vary with soil characteristics was presented in Figs. 2, 3 and 4. It can be seen that the phosphorous adsorption and equilibrium $\mathrm{P}$ concentrations were found to increase with increasing levels of added $\mathrm{P}\left(0.5-32 \mathrm{mg} \mathrm{P} \mathrm{L}^{-1}\right)$ in all the soils under investigation. In this regard Barrow (2015) reported that the amount of phosphate adsorbed by soil increases with increases in the solution concentration of phosphate. However, a sharp increase in phosphorous sorption was showed at lower concentrations and eventually approached a stable state at higher concentrations. This might be attributed to the unavailability of more adsorption sites for $\mathrm{P}$ to be adsorbed as $\mathrm{P}$ is 


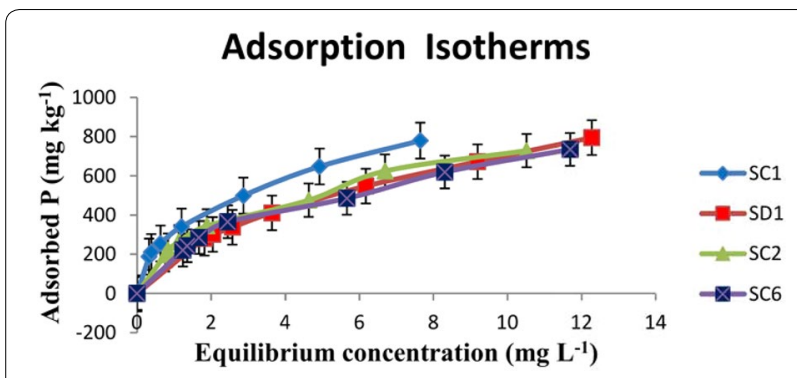

Fig. 2 Adsorption Isotherms of SC1, SD1, SC2 and SC6 soils

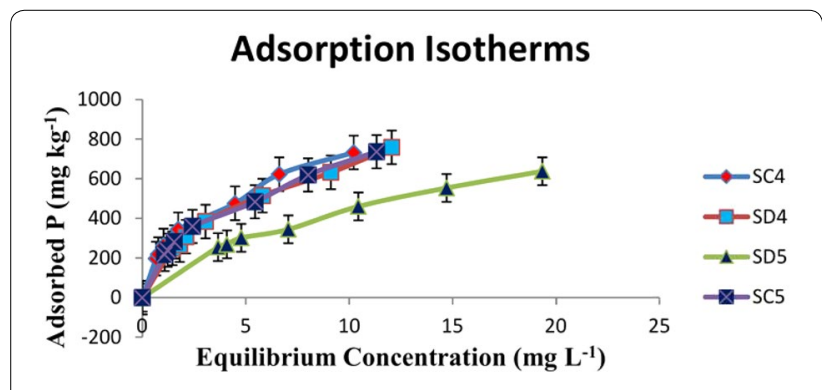

Fig. 3 Adsorption Isotherms of SC4, SD4, SD5 and SC5 soils

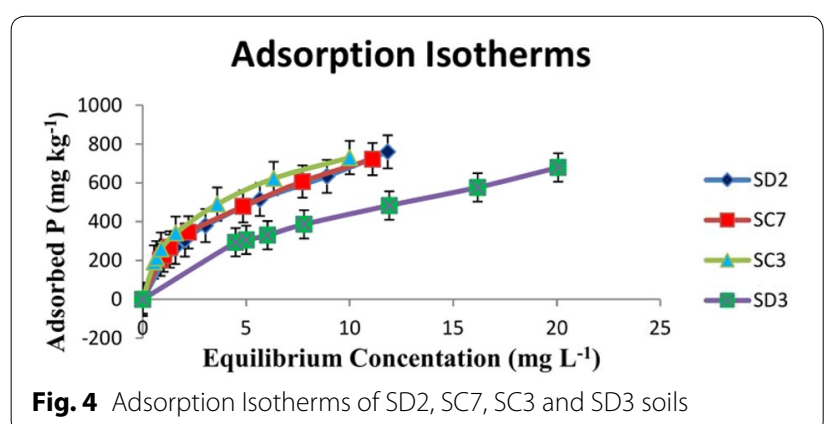

further added to the soil. In concurrent with the present study Bai et al. (2012) also found that the P adsorption on the three soils consistently showed a sharp increase at lower initial P levels, and then approached a steady state at higher phosphorus levels. The slopes of the sorption curves showed that the amount of $\mathrm{P}$ adsorbed by the soils differed among the studied soils. Therefore, it is evident from these isotherms (Figs. 2, 3 and 4) that soils in the study area exhibited different adsorption characteristics. The probable reason for this variation in adsorption capacity may be the disparity among the soils in terms of soil properties which control the availability of $\mathrm{P}$ such as $\mathrm{pH}$, clay content, organic matter,

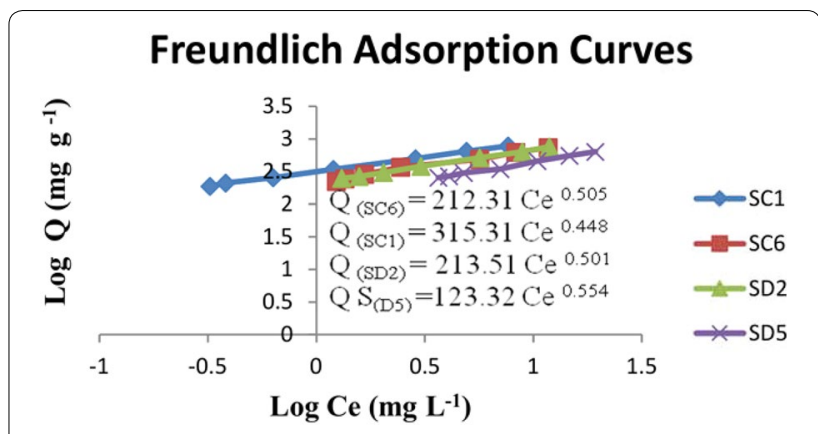

Fig. 5 Freundlich adsorption curves and equations for SC1, SC6, SD2 and SD5 soils

and oxides of $\mathrm{Al}$ or Fe (Bedin et al. 2003; Moreira et al. 2006).

\section{Phosphorous adsorption indices}

Fitting adsorption data to the adsorption equations was carried out by plotting the data in the linearized forms of the adsorption equations. The goodness of fit was evaluated by simple linear regression coefficients calculated for the linear transforms (Figs. 5, 6, 7). Plotting the adsorption data of the studied soils in the linear form of the Langmuir and Freundlich equations resulted in comparable and highly significant relationships between $\mathrm{P}$ in equilibrium solution and $\mathrm{P}$ adsorbed by soil.

The adsorption indices (coefficients) of linearized form of both models are presented in Table 3. Accordingly, the adsorption maxima $\left(\mathrm{Q}_{\max }\right)$ of the soils were ranged from 680.22 to $1112.11 \mathrm{mg} \mathrm{kg}^{-1}$ at $24 \mathrm{~h}$ equilibration period (Table 3), indicating different concentration of the strong sites $\left(\mathrm{Fe}_{\mathrm{ox}}\right.$ and $\left.\mathrm{Al}_{\mathrm{ox}}\right)$ might have influenced the adsorption capacity of the soils (Chunye et al. 2009). The lowest (680.22 $\mathrm{mg} \mathrm{P} \mathrm{kg}^{-1}$ ) and the highest (1112.11 $\mathrm{mg} \mathrm{P} \mathrm{kg}^{-1}$ ) $\mathrm{Q}_{\max }$ values were observed in SD1 and SC1 soils from the adsorption study respectively. The variations in $\mathrm{Q}_{\max }$ might be associated with the amount of $\mathrm{Fe}_{\mathrm{ox}}$ and $\mathrm{Al}_{\text {ox }}$ present in the soils. In agreement with the present study, Campos et al. (2016) examined tropical soils with $\mathrm{Q}_{\max }$ ranging from 60 to $5500 \mathrm{mg} \mathrm{kg}{ }^{-1}$, and found that $\mathrm{Al}$ and $\mathrm{Fe}$ were critical ions in controlling $\mathrm{P}$ sorption in these soils. Moreover, very inconsistent $Q_{\max }$ values have been reported by several studies from different parts of the country, of which Birru et al. (2003) selected 16 soil samples from Northwestern Highlands of Ethiopia and reported very low value (5-108 $\mathrm{mg} \mathrm{P} \mathrm{kg}^{-1}$ ) compared to the current study. On the other hand, soils under the present study appeared to have lower $\mathrm{Q}_{\max }$ as compared to acidic soils in Wonago district, southern Ethiopia (Zinabu 2015). Likewise, the $\mathrm{PBC}_{\mathrm{L}}$ determined at the standard $\mathrm{P}$ concentration in the $24 \mathrm{~h}$ of equilibration 

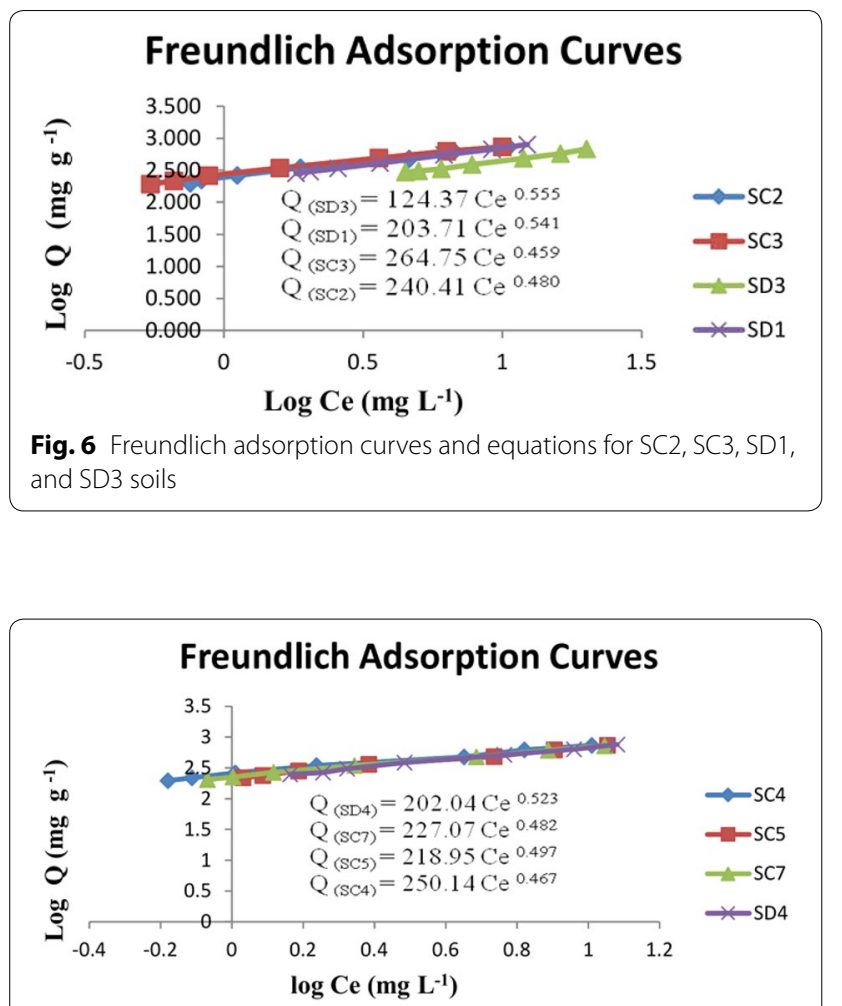

Fig. 7 Freundlich adsorption curves and equations for SC4, SC5, SD7, and SD4 soils

period ranged from 85 to $398 \mathrm{~L} \mathrm{~kg}^{-1}$ and was within the range found by Asmare (2014) and Zinabu et al. (2015) in different acidic soils of the country.
The result of the regression analysis of the data from the Langmuir model showed that the adsorption energy coefficient or binding energy constant of $\mathrm{P}$ on the adsorption sites $\left(\mathrm{K}_{\mathrm{L}}\right)$ values ranged from 0.09 to $1.13 \mathrm{~L} \mathrm{mg}^{-1}$ at $24 \mathrm{~h}$ equilibration period indicating the studied soils had variable adsorption energy coefficient. Lin and Banin (2005) reported $0.25-0.26$ and $0.02-0.05 \mathrm{~L} \mathrm{mg}^{-1}$ of the binding energy constants on the strong sites and weak sites, respectively, in the clayey sand with $0.02-0.32 \%$ of carbonate content. Therefore, the values measured in the present study roughly fall within the same magnitude as those for clayey soils. In agreement with, this study Asmare (2014) also noted that the binding energy of P on the adsorption sites of clayey acidic soils of Farta district in northwestern highlands of Ethiopia was ranged from 0.21 to $0.96 \mathrm{~L} \mathrm{mg}^{-1}$.

It is evident from the data that the energy of adsorption $\left(\mathrm{K}_{\mathrm{L}}\right)$ value was found to be greater for soils that had higher contents of oxyhydroxides of $\mathrm{Fe}$ and $\mathrm{Al}$, higher sorption capacity (PSC), higher exchangeable $\mathrm{Al}$ (exAl) and lower oxalate extractable Phosphorous $\left(\mathrm{P}_{\text {ox }}\right)$ (Tables 3).

The maximum buffering capacity (MBC) of the soil, which is the product of $\mathrm{Q}_{\max }$ and $\mathrm{K}_{\mathrm{L}}$, is a capacity factor that measures the ability of the soil to replenish phosphate ions to the soil solution (Asmare 2014). The $\mathrm{MBC}$ is potentially useful as a tool to characterize soil types especially for low concentration range because it describes both the nature and the capacity of $\mathrm{P}$ adsorption. According to the data presented in Table 3, the values of the $\mathrm{MBC}$ of the soils were ranged from 86.82

Table 3 The Freundlich and Langmuir model parameters, SPR, PBC, MBC, RMSE and $\mathbf{r}^{2}$ values after $24 \mathrm{~h}$ equilibration period

\begin{tabular}{|c|c|c|c|c|c|c|c|c|c|c|c|c|c|}
\hline \multirow{2}{*}{$\begin{array}{l}\text { Sampling } \\
\text { Sites }\end{array}$} & \multicolumn{6}{|c|}{ Freundlich parameters } & \multicolumn{7}{|c|}{ Langmuir parameters } \\
\hline & $\mathrm{K}_{\mathrm{f}}$ & $\mathbf{N}$ & RMSE & $r^{2}$ & $\operatorname{SPR}_{\mathrm{f}(0.2)}$ & $\operatorname{PBC}_{f(0.2)}$ & $\mathrm{Q}_{\max }$ & $\mathrm{K}_{\mathrm{L}}$ & RMSE & $r^{2}$ & $\mathrm{SPR}_{\mathrm{L}(\mathbf{0 . 2})}$ & $\mathrm{PBC}_{\mathrm{L}(0.2)}$ & $\mathrm{MBC}_{(0.2)}$ \\
\hline SC1 & 315.31 & 0.44 & 1.52 & 0.99 & 154.02 & 342.82 & 680.27 & 1.13 & 56.91 & 0.96 & 125.47 & 769.23 & 627.35 \\
\hline SC2 & 240.41 & 0.48 & 2.38 & 0.99 & 110.95 & 266.54 & 781.25 & 0.45 & 32.66 & 0.99 & 65.02 & 354.61 & 298.04 \\
\hline SC3 & 264.75 & 0.46 & 2.11 & 0.99 & 126.39 & 290.33 & 746.27 & 0.61 & 29.88 & 0.99 & 81.69 & 458.71 & 363.77 \\
\hline SC4 & 250.14 & 0.47 & 2.25 & 0.99 & 117.91 & 275.49 & 763.36 & 0.52 & 35.53 & 0.99 & 71.63 & 395.26 & 324.56 \\
\hline SC5 & 218.95 & 0.49 & 2.78 & 0.99 & 98.37 & 244.51 & 833.33 & 0.33 & 28.07 & 0.99 & 51.28 & 273.22 & 240.63 \\
\hline SC6 & 212.14 & 0.50 & 2.93 & 0.99 & 94.04 & 237.67 & 884.96 & 0.28 & 21.27 & 0.99 & 46.34 & 244.49 & 219.56 \\
\hline SC7 & 227.07 & 0.48 & 2.59 & 0.99 & 104.44 & 251.99 & 769.23 & 0.41 & 30.74 & 0.99 & 58.31 & 315.46 & 269.44 \\
\hline SD1 & 203.71 & 0.54 & 3.44 & 0.99 & 85.23 & 230.71 & 1112.11 & 0.19 & 18.22 & 0.98 & 39.92 & 207.04 & 192.43 \\
\hline SD2 & 213.51 & 0.50 & 3.01 & 0.99 & 95.33 & 238.81 & 847.46 & 0.29 & 33.44 & 0.98 & 46.99 & 248.76 & 221.93 \\
\hline SD3 & 124.37 & 0.55 & 6.43 & 0.99 & 50.85 & 141.29 & 943.39 & 0.09 & 14.88 & 0.97 & 17.69 & 90.17 & 86.82 \\
\hline SD4 & 202.04 & 0.53 & 3.23 & 0.99 & 86.13 & 228.14 & 925.93 & 0.24 & 19.61 & 0.98 & 42.05 & 220.26 & 200.71 \\
\hline SD5 & 123.32 & 0.55 & 5.88 & 0.99 & 50.50 & 140.06 & 869.56 & 0.11 & 12.39 & 0.98 & 18.62 & 95.15 & 91.11 \\
\hline Mean & 216.31 & 0.502 & 3.21 & 0.99 & 97.85 & 240.69 & 846.34 & 0.39 & 27.80 & 0.98 & 55.42 & 306.03 & 261.36 \\
\hline
\end{tabular}

$K_{f}$ amount of $\mathrm{P}$ adsorbed, $N$ slope, $R M S E$ root mean square error, $S P R_{f}$ standard $\mathrm{P}$ requirement from Freundlich model, $P B S_{f}$ phosphorous buffering capacity from Freundlich model, $Q_{\max }$ maximum adsorption, $K_{L}$ affinity coefficient, $S P R$ standared $P$ requiremnts, $P B C$ phosphorous buffering capacity, $M B C$ maximum buffering capacity 
to $627.35 \mathrm{~L} \mathrm{~kg}^{-1}$. It can be seen that soils with higher adsorption capacity, $\mathrm{Fe}_{\mathrm{ox}}$ and $\mathrm{Al}_{\mathrm{ox}}$ concentration, clay percent and exchangeable $\mathrm{Al}$ were appeared to have higher maximum buffering capacity. The soils with the highest $\mathrm{MBC}$ (SC1 and $\mathrm{SC} 3$ ) have higher adsorption capacity, reflecting low $\mathrm{P}$ supply into soil solution for a longer period as compared to the less buffered soils which can supply ample P to soil solution. On the other hand, soils with low buffering capacity will have more $\mathrm{P}$ in soil solution and will enhance P mobility in such soils.

The Freundlich adsorption capacity $\left(\mathrm{K}_{\mathrm{f}}\right)$, which is a measure of the reactive surface area (relative adsorption capacity) of the soil, is presented in Table 3. It has been shown that the $\mathrm{K}_{\mathrm{f}}$ values ranged from 123.32 (SD5) to 315.31 (SC1) $\mathrm{mg} \mathrm{kg}^{-1}$ respectively. It may be seen that the $K_{f}$ value was higher for the high $P$ adsorbing soils that adsorb more $\mathrm{P}$ per $\mathrm{kg}$ soil than the low $\mathrm{P}$ adsorbing soils indicating strong affinity of adsorbate $(\mathrm{P})$ towards the adsorbent surfaces (soil). The variation observed in $\mathrm{P}$ sorption capacities $\left(\mathrm{K}_{\mathrm{f}}\right)$ among soils from the assorted sites might be ascribed to differences in oxides of $\mathrm{Al}$ and Fe and clay content in soils (Obura 2008). Moreover, the $\mathrm{K}_{\mathrm{f}}$ values of the current study were in the range found by Birru et al. (2003) who reported 90-4915 mg P kg-1 for acidic soils of north western highland of Ethiopia.

Phosphorous buffer capacity (PBC) of soils plays an important role in both agronomic and environmental aspects of P management (Ehlert et al. 2003). Sorption isotherms are much used to characterize the retention of $\mathrm{P}$ and the $\mathrm{PBC}_{\mathrm{f}}$ of soil (Yli-halla et al. 2002). Accordingly, the phosphorous buffer capacity was obtained for soils of each district from the slope of the linear equation by plotting $\mathrm{P}$ adsorbed against $\mathrm{P}$ equilibrium concentration at $0.2 \mathrm{mg} \mathrm{L}^{-1}$. The result of this study indicated that $\mathrm{PBC}_{\mathrm{f}}$ values determined at the standard $\mathrm{P}$ concentration of $0.2 \mathrm{mg} \mathrm{P} \mathrm{L}^{-1}$ increased with increase in the $\mathrm{K}_{\mathrm{f}}$ values.

\section{Model validation and interpretation}

The $\mathrm{P}$ adsorption data fitted to the linearized Langmuir and Freundlich models are shown in Table 3. The coefficients of determination $\left(\mathrm{R}^{2}\right)$ for the Freundlich model (0.99-1.00) were almost slightly greater than the Langmuir model $(0.98-0.99)$ in the studied soils. Furthermore, the average distance at which the observed values deviated from the regression line (RMSE) of the Freundlich model (5.4-9.8) was smaller than that of the Langmuir model (19.8-28.0) (Table 3). Hence, the Freundlich model can be considered as a superior model for the description of the $\mathrm{P}$ adsorption characteristics of the soils in this particular study because of its lower (RMSE) and slightly higher $\mathrm{R}^{2}$ values. Moreover, the Freundlich model, although originally empirical, implies that the affinity for adsorption decreases exponentially with increasing saturation of the surface which is closer to reality than the assumption of constant bonding energy inherent in the Langmuir equation. Therefore, phosphorous sorption by the studied soil was well described by the Freundlich equation.

The Freundlich constants $\mathrm{K}_{\mathrm{f}}$ and $\mathrm{N}$, which represent the intercept and slope of the log-transformed sorption isotherm, may be taken as a measure of the extent of adsorption and the energy of adsorption, for the thoughtout soils respectively. The former could also be considered as capacity factor implying that a soil having larger $\mathrm{K}_{\mathrm{f}}$ value has superior adsorbing capacity than otherwise. The Freundlich coefficient $K_{\mathrm{f}}$ ranged from 123.32 to $315.31 \mathrm{mg} \mathrm{P} \mathrm{kg}^{-1}$ (Table 3). In this study, SC1 exhibited the highest $\mathrm{K}_{\mathrm{f}}\left(315.31 \mathrm{mg} \mathrm{P} \mathrm{kg}{ }^{-1}\right)$ value where as SD5 did show the lowest $K_{f}\left(123.32 \mathrm{mg} \mathrm{P} \mathrm{kg}^{-1}\right)$. The order of soils according to their adsorption capacities is found to be: $\mathrm{SC} 1>\mathrm{SC} 3>\mathrm{SC} 4>\mathrm{SC} 5>\mathrm{SC} 6>\mathrm{SC} 2>\mathrm{SC} 7>\mathrm{SD} 2>\mathrm{SD} 4>\mathrm{S}$ $\mathrm{D} 1>\mathrm{SD} 3>\mathrm{SD} 5$. The observed difference in $\mathrm{K}_{\mathrm{f}}$ value of the soils in the study area might be due to the disparity in the distribution of oxyhydroxides of Fe and $\mathrm{Al}$. It has been noted that adsorption of $\mathrm{P}$ in soils is controlled to a large extent by the presence of amorphous $\mathrm{Fe}$ and $\mathrm{Al}$ (Agbenin 2003; Yan et al. 2013). These values are relatively high and comparable with those found by Asmare (2014) for the acidic soils of Farta district, northwestern highlands of Ethiopia which varied from 80 to $259 \mathrm{mg} \mathrm{P} \mathrm{kg}^{-1}$. On the other hand the soils were found to have lower $K_{f}$ value compared to the one reported and by Zinabu et al. (2015) in acidic soils from Bule district, southern Ethiopia, which varied from 479 to $487 \mathrm{mg} \mathrm{P} \mathrm{kg}^{-1}$. The exponent term $(\mathrm{N})$ in the Freundlich relationship describing solid phase $\mathrm{P}$ and solution $\mathrm{P}$ at equilibrium is less than one for all of the soils (Table 3 ). This indicates that the relationship is not curvilinear and suggests that adsorption of $\mathrm{P}$ is controlling solution $\mathrm{P}$ concentrations in most of the soils (Bertrand et al. 2003).

Phosphorus buffer capacity was obtained for each soil from the slope of the linear equation by plotting $\mathrm{P}$ adsorbed against $\mathrm{P}$ concentration at equilibrium for the adsorption dominated part of the isotherm (0.5$\left.32 \mathrm{mg} \mathrm{P} \mathrm{L}{ }^{-1}\right)$. Phosphorous buffer capacity $\left(\mathrm{PBC}_{\mathrm{f}}\right)$ of the soils varied from 140.06 to $342.82 \mathrm{~L} \mathrm{~kg}^{-1}$ (Table 3). In the current study, all the studied soils appeared to have a very high $\mathrm{PBC}_{\mathrm{f}}$ (Moody and Bolland 1999), the soils from Cheha being higher. It can be inferred that more added fertilizer P could be adsorbed, as I or Q is increased (Jensen and Jakobsen 1970) in soil samples from Cheha district compared to soils from Dinsho district. Moreover, the soils with the highest $\mathrm{PBC}$ (SC1) have higher adsorption capacity and would maintain low P supply in soil solution for a longer period as compared to least (SD5) buffered soils which can supply ample P to soil solution. 
On the other hand, soils with low buffering capacity will have more $\mathrm{P}$ in soil solution and will enhance $\mathrm{P}$ mobility in such soils. About $75 \%$ of the studied soils were within the range found by Asmare (2014) for eight acidic soils of northwestern highlands of Ethiopia.

\section{Standard phosphorus fertilizer requirements (SPR)}

The $S P R_{\mathrm{f}}$ of the soils calculated from the Freundlich equation (Table 3) at $0.2 \mathrm{mg} \mathrm{P} \mathrm{L}^{-1}$ is an estimate of P sorption potential (Jackman et al. 1997; Wang et al. 2000). The amount of $\mathrm{P}$ adsorbed at an equilibrium concentration of $0.2 \mathrm{mg} \mathrm{P} \mathrm{L} \mathrm{L}^{-1}$ was between 50.50 and $154.02 \mathrm{mg} \mathrm{P} \mathrm{kg}^{-1}$ of soil. Fox (1981) and Afif et al. (1993) indicated that this concentration $\left(0.2 \mathrm{mg} \mathrm{P} \mathrm{L}^{-1}\right)$ is an adequate external $\mathrm{P}$ requirement for most crops. The value of $\mathrm{SPR}_{\mathrm{f}}$ ranged from 94.04 to $154.02 \mathrm{mg} \mathrm{P} \mathrm{kg}^{-1}$ for the soils of Cheha district. Similarly, the $\mathrm{SPR}_{\mathrm{f}}$ of soils in Dinsho district varied from 50.50 to $95.33 \mathrm{mg} \mathrm{kg}^{-1}$. The distinction in adsorption capacities of these soils might be ascribed to the difference in abundance and distribution of strongly reactive $\mathrm{P}$ adsorption sites on amorphous $\mathrm{Fe}$ and $\mathrm{Al}$ oxides (Chunye et al. 2009). In this regard different studies realized that $\mathrm{Fe}_{\mathrm{ox}}$ and $\mathrm{Al}_{\mathrm{ox}}$ were considered to be the key factors in regulating $\mathrm{P}$ adsorption due to its large surface area, variable-charge surface and high reactivity, especially in redox-changing environments (Makris et al. 2005; Wang et al. 2009; Yan et al. 2016). The higher values of $\mathrm{SRP}_{\mathrm{f}}$ in case of Cheha soils indicate the need for application of more $P$ fertilizers to maintain optimum crop production compared to soils collected from Dinsho district.

According to Sanchez and Uehara (1980), soils (SC2, SC3, SC4, SC5, SC6, SC7, SD1, SD2, SD3, SD4 and SD5) that adsorb less than $150 \mathrm{mg} \mathrm{P} \mathrm{kg}{ }^{-1}$ soil to meet the $\mathrm{SPR}_{\mathrm{f}}$ value of $0.2 \mathrm{mg} \mathrm{L}^{-1}$ in soil solution were considered to be low adsorbing soil and the other adsorbing an amount exceeding this value was high $\mathrm{P}$ adsorbing ones (SC1). Furthermore, the results of the current study on the subject of SPR of these soils presented a comparable result with those found by Asmare (2014); Zinabu (2015) and Duffera and Robarge (1999) in different highly weathered acidic soils of Ethiopia (42-175 $\mathrm{mg} \mathrm{P} \mathrm{kg}^{-1}$ ) in West Africa (Abekoe and Sahrawat 2001). As a case in point Duffera and Robarge (1999) reported that the amount of added $\mathrm{P}$ required maintaining a concentration of $0.2 \mathrm{mg} \mathrm{P} \mathrm{L}^{-1}$ in solution (SPR) ranged from 50 to $201 \mathrm{mg} \mathrm{P} \mathrm{kg}^{-1}$ for surface soil samples from non-cultivated and non-fertilized areas in Ethiopia. Likewise, Zinabu et al. (2015) has found that the SPR values of acidic soils of Bule and Wonago districts in southern Ethiopia ranging from 71.8 to $211 \mathrm{mg} \mathrm{kg}^{-1}$.

The consumption of fertilizers in sub Saharan Africa was estimated to be $8 \mathrm{~kg} \mathrm{P} \mathrm{ha}^{-1}$ (Morris et al. 2007) and the blanket recommendation for cereal crops in Ethiopia was $20 \mathrm{~kg} \mathrm{P} \mathrm{ha}{ }^{-1}$. However, in the present study at the $24 \mathrm{~h}$ of equilibration time, the $\mathrm{SPR}_{\mathrm{f}}$ of the soils ranged from 50.50 to $154.02 \mathrm{mg} \mathrm{P} \mathrm{kg}^{-1}$ which was equivalent to the application of 115.64 to $352.71 \mathrm{~kg} \mathrm{P} \mathrm{ha}^{-1}$ and superior than the blanket recommendation in Ethiopia by about a factor of 6-18.The differences in the $\mathrm{SPR}_{\mathrm{f}}$ of the soils in the study sites indicate that application of blanket $\mathrm{P}$ fertilizer rates for all study sites is not feasible. The blanket recommendation of $\mathrm{P}$ fertilizer for Ethiopian soils is therefore, inadequate for optimal crop production at all the sites. This is because it can supply at most only $20 \mathrm{~kg} \mathrm{P} \mathrm{ha}{ }^{-1}$, which is much below the soils $\mathrm{SPR}_{\mathrm{f}}$ of $115.64-352.71 \mathrm{~kg} \mathrm{P} \mathrm{ha}^{-1}$. Soils of the study area were found to have analogous $\mathrm{SPR}_{\mathrm{f}}$ values with soils appraised by Asmare (2014), where the application of P fertilizers based on the blanket recommendation in the northwestern highlands of Ethiopia could result in a substantial yield deficit. Therefore, a mechanism has to be devised to increase availability of $\mathrm{P}$ by attenuating the $\mathrm{P}$ high adsorption capacity of the soils in order to increase productivity especially for soils with relatively high $\mathrm{P}$ fixing capacity (Cheha district).

The $\operatorname{SPR}_{\mathrm{f}}\left(0.2 \mathrm{mg} \mathrm{L}^{-1}\right)$ levels for the studied soils that were obtained after $24 \mathrm{~h}$ equilibration periods were not remain similar and the soil solution $\mathrm{P}$ (intensity factor) depends on the adsorbed $\mathrm{P}$ (capacity factor) or the buffering capacity of the soils (Fox 1981). Consequently, the use of soil test $\mathrm{P}$ fertilizer recommendation based on the adsorption curves together with plant response for the applied P for different crop varieties should be done for the soils of the study area rather than using the usual conventional practice which could underestimate or overestimate the amount $\mathrm{P}$ fertilizer to be applied. Since the $\mathrm{SPR}_{\mathrm{f}}$ of the soils calculated from the Freundlich equation (Table 3 ) is an estimate of $P$ sorption potential (Wang et al. 2000) and an adequate external P requirement for most crops (Afif et al. 1993), diverse crop varieties in the study area could require different amount of $\mathrm{P}$ fertilizer. Thus it could be inferred that the external and internal P requirement of a crop as well as variety has to be investigated to find a reasonable amount of fertilizer to be applied to a particular soil with respect to crops and sites.

\section{Correlation between Freundlich adsorption indices and soil properties}

The correlation analysis was done between the Freundlich adsorption indices $\left(\mathrm{K}_{f}, \mathrm{PBC}_{\mathrm{f}}\right.$, and $\left.\mathrm{SPR}_{\mathrm{f}}\right)$ and the various soil properties (Clay, exAl, CEC, OC, $\mathrm{P}_{\mathrm{ox}}$, $\mathrm{Al}_{\text {ox }}, \mathrm{Fe}_{\text {ox }}$, Mhlich $3 \mathrm{P}, \mathrm{NH}_{4} \mathrm{Cl}-\mathrm{P}, \mathrm{NaOH}-\mathrm{Pi}$ and $\mathrm{HCl}-\mathrm{P}$ ) and presented in Table 4. Adsorption parameters were strongly and positively correlated with soil properties i.e., $\left[\mathrm{r}=0.89, \mathrm{P} \leq 0.01\left(\mathrm{~K}_{\mathrm{f}}\right.\right.$ and $\left.\mathrm{Fe}_{\mathrm{ox}}\right) ; \mathrm{r}=0.87, \mathrm{P} \leq 0.01$ 
Table 4 Correlation table for Freundlich model coefficients and soil properties

\begin{tabular}{|c|c|c|c|c|c|c|c|c|c|c|c|}
\hline & CEC & $M-3 P$ & $A I_{o x}$ & $\mathrm{Fe}_{\text {ox }}$ & OC & Clay & $\mathrm{HCl}-\mathrm{P}$ & $\mathrm{NaOHPi}$ & $\mathrm{NH}_{4} \mathrm{Cl}-\mathrm{P}$ & $P_{\text {ox }}$ & exAl \\
\hline$K_{f}$ & $-0.81^{* *}$ & $-0.79^{* *}$ & $0.87^{* *}$ & $0.89^{* *}$ & $-0.86^{* *}$ & $0.84^{* *}$ & $-0.75^{* *}$ & $0.62^{*}$ & $-0.84^{* *}$ & $-0.91^{* *}$ & $0.78^{* *}$ \\
\hline $\mathrm{PBC}_{\mathrm{f}}$ & $-0.80^{* *}$ & $-0.78^{* *}$ & $0.86^{* *}$ & $0.88^{* *}$ & $-0.85^{* *}$ & $0.84^{* *}$ & $-0.74^{* *}$ & $0.61^{*}$ & $-0.84^{* *}$ & $-0.91^{* *}$ & $0.77^{* *}$ \\
\hline SPR & $-0.84^{* *}$ & $-0.83^{* *}$ & $0.89^{* *}$ & $0.91^{* *}$ & $-0.89^{* *}$ & $0.85^{* *}$ & $-0.77^{* *}$ & $0.65^{*}$ & $-0.86^{* *}$ & $-0.91^{* *}$ & $0.81^{* *}$ \\
\hline N & $0.90^{* *}$ & $0.94^{* *}$ & $-0.94^{* *}$ & $-0.94^{* *}$ & $0.93^{* *}$ & $-0.90^{* *}$ & $0.88^{* *}$ & $-0.77^{* *}$ & $0.93^{* *}$ & $0.93^{* *}$ & $-0.79^{* *}$ \\
\hline
\end{tabular}

CEC cation exchange capacity, $\mathrm{M}-3 \mathrm{P}$ Mehlich-3 $\mathrm{P}, \mathrm{Al}$ ox oxalte extractable $\mathrm{Al}, \mathrm{Fe}$ ox oxalate extractable $\mathrm{Fe}, \mathrm{OC}$ organic carbon, $\mathrm{HCl}-\mathrm{P} \mathrm{HCl}$ extractable $\mathrm{P}, \mathrm{NaOH}-\mathrm{Pi} \mathrm{NaOH}$

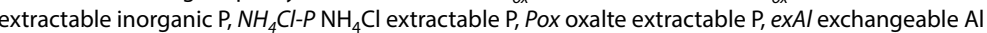

$\left(\mathrm{K}_{\mathrm{f}}\right.$ and $\left.\mathrm{Al}_{\mathrm{ox}}\right) ; \mathrm{r}=0.89, \mathrm{P} \leq 0.01\left(\mathrm{Al}_{\mathrm{ox}}\right.$ and $\left.\mathrm{SPR}_{\mathrm{f}}\right) ; \mathrm{r}=0.84$, $\mathrm{P} \leq 0.01\left(\mathrm{~K}_{\mathrm{f}}\right.$ and Clay); $\mathrm{r}=0.62, \mathrm{P} \leq 0.05(\mathrm{NaOH}-\mathrm{pi}$ and $\left.\mathrm{K}_{\mathrm{f}}\right) ; \mathrm{r}=0.81, \mathrm{P} \leq 0.01\left(\mathrm{exAl}\right.$ and $\left.\mathrm{SPR}_{\mathrm{f}}\right) ; \mathrm{r}=0.91, \mathrm{P} \leq 0.01$ $\left(\mathrm{Fe}_{\mathrm{ox}}\right.$ and $\left.\mathrm{SPR}_{\mathrm{f}}\right) ; \mathrm{r}=0.89, \mathrm{P} \leq 0.01\left(\mathrm{Al}_{\mathrm{ox}}\right.$ and $\left.\left.\mathrm{SPR}_{\mathrm{f}}\right)\right]$. The adsorption parameters were positively and strongly correlated with $\mathrm{Fe}_{\text {ox }}$ and $\mathrm{Al}_{\text {ox }}$ indicating the presence of reactive and strong $\mathrm{P}$ adsorption sites on $\mathrm{Fe}$ and $\mathrm{Al}$ oxides (Chunye et al. 2009). The presence of high correlation between the adsorption parameters and the oxalate extractable $\mathrm{Al}$ and Fe suggest that those adsorption coefficients did play a prominent role in explaining $\mathrm{P}$ adsorption characteristics of the soils in terms of oxides of $\mathrm{Fe}$ and $\mathrm{Al}$ in the study area. It can also be seen from the correlation study that in soils where there was higher clay content, exAl, $\mathrm{Al}_{\mathrm{ox}}$ and $\mathrm{Fe}_{\mathrm{ox}}$, concurrently higher $\mathrm{SPR}_{\mathrm{f}}, \mathrm{PBC}$ and $\mathrm{K}_{\mathrm{f}}$ values were observed. It verified the expectation that higher phosphorous buffering capacity, fertilizer requirements and adsorption capacity is expected in soils where clay content, exAl and oxides of $\mathrm{Fe}$ and $\mathrm{Al}$ are dominating. This confirmed the significant influence of soil texture on P sorption capacity as reported by several authors (Yuan and Lucas 1982; Mozaffari and Sims 1994).

A significant and negative correlation was found between the soil properties (CEC, OC, $\mathrm{P}_{\mathrm{ox}}, \mathrm{NH}_{4} \mathrm{Cl}-\mathrm{P}$, and $\mathrm{HCl}-\mathrm{P}$ ) and the Freundlich adsorption parameters. However, $\mathrm{NaOH}-\mathrm{Pi}$ was strongly and positively $(\mathrm{p} \leq 0.01)$ correlated with adsorption coefficients. The compelling reason for strong positive association between $\mathrm{NaOH}-\mathrm{Pi}$ and the adsorption parameters could be the greater contents of oxyhydroxides of $\mathrm{Fe}$ and $\mathrm{Al}$ which in turn vigorously stabilize $\mathrm{NaOH}-\mathrm{Pi}$ in the soil (Yan et al. 2017). The significant and negative correlation between the organic carbon content and adsorption indices $\left(\mathrm{K}_{\mathrm{f}}, \mathrm{SPR}_{\mathrm{f}}\right.$ and $\left.\mathrm{PBC}_{\mathrm{f}}\right)(r=-0.86$, $\mathrm{P} \leq 0.01 ; \quad \mathrm{r}=-0.89, \quad \mathrm{P} \leq 0.01, \quad \mathrm{r}=-0.85, \quad \mathrm{P} \leq 0.01)$ respectively, for soils was concurrent with several reports (Juo and Fox 1977 and Daly et al. 2001). However, there are results indicating positive correlation as well (Wild 1950; Börling et al. 2001). Moreover, as case in point other research results showed that $\mathrm{OC}$ can have a significant and positive relationship (Ayaz et al.
2010) and significant negative relationship (Burt et al. 2002; Moazed et al. 2010) with the adsorption capacity of the soils. From this strong association between these parameters and soil properties it could be inferred that in soils where we found high CEC, OC, $\mathrm{P}_{\mathrm{ox}}, \mathrm{NH}_{4} \mathrm{Cl}-\mathrm{P}$ and $\mathrm{HCl}-\mathrm{P}$ there would be low adsorption capacity, phosphorus buffering capacity and phosphorous fertilizer requirements. Thus, the coefficients $\mathrm{k}_{\mathrm{f}}$ (amount adsorbed), $\mathrm{PBC}_{\mathrm{f}}$ (Phosphorous buffering capacity), $\mathrm{SPR}_{\mathrm{f}}$ (standard phosphorous requirement) and $\mathrm{N}$ (buffer power) of Freundlich adsorption model were best predicted from CEC, Mehlich-3 $\mathrm{P}$ HCl-P, $\mathrm{NH}_{4} \mathrm{Cl}-\mathrm{P}$, clay, $\mathrm{Fe}_{\mathrm{ox}}, \mathrm{Al}_{\mathrm{ox}}, \mathrm{NaOH}-\mathrm{pi}$ and exAl and $\mathrm{P}_{\mathrm{ox}}$ and therefore put forth a profound influence on the rate of $\mathrm{P}$ adsorbed onto the soils.

\section{Conclusions}

The adsorption study was conducted to found the relationship between adsorbed $\mathrm{P}$ and solution $\mathrm{P}$ to appraise the $\mathrm{P}$ adsorption properties of the soils by making use of appropriate empirical model and evaluate the correlation between adsorption indices and soil properties. The Freundlich model could be considered as the best model for the description of the $\mathrm{P}$ adsorption characteristics of the soils in this particular study area. The Freundlich coefficient $\mathrm{K}_{\mathrm{f}}$ (adsorption capacity) value ranged from 123.32 to $315.31 \mathrm{mg} \mathrm{P} \mathrm{kg}^{-1}$ and depended on amorphous form of $\mathrm{Fe}$ and $\mathrm{Al}$ (i.e. $\mathrm{Fe}_{\mathrm{ox}}$ and $\mathrm{Al}_{\mathrm{ox}}$ ). Consequently, the standard $\mathrm{P}$ requirements of the soils varied from 50.50 to $154.02 \mathrm{mg} \mathrm{P} \mathrm{kg}^{-1}$ of soil, implying the blanket recommendation of $\mathrm{P}$ fertilizer for Ethiopian soils is therefore, inadequate for optimal crop production in the study area and was much below the soils' actual $\mathrm{P}$ requirements. Phosphorous buffer capacity $\left(\mathrm{PBC}_{\mathrm{f}}\right)$ of the soils varied from 140.06 (SD5) to $342.82 \mathrm{~L} \mathrm{~kg}^{-1}$ (SC1) and all of the premeditated acidic soils $(100 \%)$ was classified under very high $(>90)$ phosphorous buffering capacity soils and would maintain low P supply in soil solution for a longer period. Strong and positive significant relationship was observed between the Freundlich adsorption parameters $\left(\mathrm{K}_{\mathrm{f}}, \mathrm{PBC}_{\mathrm{f}}\right.$ and $\left.\mathrm{SPR}_{\mathrm{f}}\right)$ and oxalate extractable $\mathrm{Al}$ and $\mathrm{Fe}$ $(\mathrm{P} \leq 0.01)$. The Freundlich adsorption coefficients play a prominent role in explaining $P$ adsorption characteristics 
of the soils in terms of oxides of $\mathrm{Fe}$ and $\mathrm{Al}$ in the study area. The amount of $\mathrm{P}$ adsorbed, Phosphorous buffering capacity, standard phosphorous requirement of the soils were best predicted from CEC, Mehlich-3 P HCl-P, $\mathrm{NH}_{4} \mathrm{Cl}-\mathrm{P}$, clay, $\mathrm{Fe}_{\text {ox }}, \mathrm{Al}_{\text {ox }}, \mathrm{NaOH}$-pi and exAl and $\mathrm{P}_{\text {ox }}$ and therefore put forth a considerate influence on the rate of $\mathrm{P}$ adsorbed onto the soils. Therefore, a mechanism has to be devised to increase availability of $\mathrm{P}$ by attenuating the $\mathrm{P}$ adsorption capacity of the soils in order to increase productivity especially for soils with relatively high $\mathrm{P}$ fixing capacity. The blanket $\mathrm{P}$ fertilizer rate recommendations in Ethiopia without the knowledge of external $\mathrm{P}$ requirement of each crop might have decreased yield in the study areas as it could have resulted in under-application of fertilizer P. Thus it could be inferred that the external and internal $P$ requirement of a crop as well as variety has to be investigated to find a reasonable amount of fertilizer to be applied to a particular soil with respect to crops and sites.

\begin{abstract}
Abbreviations
$\mathrm{Q}_{\text {max }}$ : adsorption maximum; Q: amount $\mathrm{P}$ adsorbed; CEC: cation exchange capacity; DPS: degree of phosphorous saturation; DCB: dithionite-citrate-bicarbonate; Ce: equilibrium P concentrations; EDTA: ethylene diaminetetraacetic acid; FAO: Food and Agriculture organization; $\mathrm{K}_{\mathrm{f}}$. Freundlich adsorption capacity; GPS: geographic position system; $K_{L}$ : Langmuir energy of adsorption; $M B C$ : maximum buffering capacity; $\mathrm{Al}_{\text {ox }}$ : oxalte extractable aluminium; $\mathrm{Fe}_{\text {ox: }}$ oxalte extractable iron; PBC: phosphorous buffering capacity; PSC: phosphorous sorption capacity; RMSE: root mean square error; SNNP: South Nation Nationalities and people; SPR: standard phosphorous requirement; SAS: statistical analysis system.
\end{abstract}

\section{Authors' contributions}

BA: collected, analyzed, interpreted the data and made the final write up which was part of his Doctoral thesis in Soil Science at Haramaya University, Ethiopia. AMT, KK and AM, as co-authors edited the final manuscript. All authors read and approved the final manuscript.

\section{Author details}

${ }^{1}$ School of Natural Sciences, Department of Chemistry, Madda Walabu University, Bale-Robe, Ethiopia. ${ }^{2}$ Department of Chemistry, College of Natural and Computational Sciences, Haramaya University, Dire Dawa, Ethiopia. ${ }^{3}$ School of Natural Resources Management and Environmental Sciences, Haramaya University, Dire Dawa, Ethiopia. ${ }^{4}$ Department of Plant Science, College of Agriculture and Natural Resource Sciences, Debre Berhan University, Debre Berhan, Ethiopia.

\section{Acknowledgements}

The project was funded by SIDA (Swedish International Development Cooperation Agency) and Madawalabu University. Thus, we would like to thank these institutions. We would also like to thank the anonymous reviewers who contributed significantly to the improvement of the article.

\section{Competing interests}

The authors declare that they have no competing interests.

\section{Availability of data and materials}

$$
\text { Not applicable. }
$$

\section{Consent for publication}

Not applicable.
Ethics approval and consent to participate "Not applicable".

\section{Funding}

Swedish International Cooperation Development Agency (SIDA) and Ministry of Education provided fund only for sample collection and laboratory analysis.

\section{Publisher's Note}

Springer Nature remains neutral with regard to jurisdictional claims in published maps and institutional affiliations.

Received: 8 March 2018 Accepted: 16 July 2018

Published online: 28 July 2018

\section{References}

Abekoe MK, Sahrawat KL (2001) Phosphate retention and extractability in soils of the humid zone in West Africa. Geoderma 102:175-187

Afif E, Matar A, Torrent J (1993) Availability of phosphate applied to calcareous soils of West Asia and North Africa. Soil Sci Soc Am J 57:756-760

Agbenin JO (2003) Extractable iron and aluminum effects on phosphate sorption in a savanna alfisol. Soil Sci Soc Am J 67:589-595

Ahmed MF, Kennedy IR, Choudhury ATMA, Kecskes ML, Deaker R (2008) Phosphorous adsorption in some Australine soils and influence of bacteria on the desorption of phosphorous. Commun soil sci Plant Anal 39:1269-1294

Al Baquy MA, Li JY, Chen YX, Khalid M, Xu RK (2017) Determination of critical $\mathrm{pH}$ and $\mathrm{Al}$ concentration of acidic Ultisols for wheat and canola crops. Solid Earth 8: 149-159. www.solid-earth.net/8/149/2017/. https://doi. org/10.5194/se-8-149-2017

Amrani M, Westfall DG, Moughli L (1999) Phosphate sorption in calcareous Moroccan soils as affected by soil properties. Commun Soil Sci Plant Anal 30(9-10):1299-1314

Asmare (2014) Phosphorus adsorption characteristics and kinetics of acid soils of Farta District, Northwestern highlands of Ethiopia. A PhD dissertation submitted to the School of Natural Resources Management and Environmental Sciences, School of Graduate Studies, Haramaya University

Asmare M, Heluf G, Markku YH, Birru Y (2015) Phosphorus status, inorganic phosphorus forms, and other physicochemical properties of acid soils of Farta district, Northwestern highlands of Ethiopia. Appl Environ Soil Sci. https://doi.org/10.1155/2015/748390 (Article ID 748390)

Ayaz M, Saleem A, Memon M (2010) Phosphorus adsorption parameters in relation to soil characteristics. J Chem Soc Pak 32:129-139

Bahia FAFC, Braga JM, Resende M, Ribeiro AC (1983) Relationship between phosphorus adsorption and mineralogical components of latosols clay fraction of the central plateau. Braz J Soil Sci 7:221-226

Bai JH, Wang JJ, Yan DH, Gao HF, Xiao R, Shao HB, Ding QY (2012) Spatial and temporal distributions of soil organic carbon and total nitrogen in two marsh wetlands with different flooding frequencies of the Yellow River Delta, China. Clean Soil Air Water 40(10):1137-1144

Barrow NJ (2015) A mechanistic model for describing the sorption and desorption of phosphate by soil. Eur J Soil Sci 66:9-18. https://doi. org/10.1111/ejss.12198-2

Bedin I, Furtini NAE, Resende AV, Faquin V, Tokura AM, Santos JZL (2003) Phosphate fertilizers and soybean production in soils with different phosphate buffer capacities. Braz J Soil Sci 27:639-646

Bereket (2017) Chemical forms of phosphorous and physicochemical properties of acidic soils of Cheha and Dinsho districts, southern highlands of Ethiopia. A PhD dissertation submitted to the School of Natural Resources Management and Environmental Sciences, School of Graduate Studies, Haramaya University

Bertrand I, Holloway RE, Armstrong RD, McLaughlin MJ (2003) Chemical characteristics of phosphorus in alkaline soils from southern Australia. Aust J Soil Res 41:61-76

Birru Y, Heluf G, Gupta VP (2003) Sorption characteristics of soils of the northwestern highlands of Ethiopia. Ethiop J Nat Resour 5:1-16

Börling K, Otabbong E, Barberis E (2001) Phosphorus sorption in relation to soil properties in some cultivated Swedish soils. Nutr Cycl Agroecosyst 59:39-46 
Burt R, Mays MD, Benham EC, Wilson MA (2002) Phosphorus characterization and correlation with properties of selected bench mark soil of the United States. Commun Soil Sci Plant Anal 33:117-142

Campos MD, Antonangelo JA, Alleoni LRF (2016) Phosphorus sorption index in humid tropical soils. Soil Tillage Res 156:110-118

Chen GC, He ZL, Huang CY (2000) Microbial biomass phosphorus and its significance in predicting phosphorus availability in red soils. Commun Soil Sci Plant Anal 31:655-667

Chunye L, Zhigang W, Mengchang H, Yanxia L, Ruimin L, Zhifeng Y (2009) Phosphorus sorption and fraction characteristics in the upper, middle and low reach sediments of the Daliao river systems, China. J Hazard Mater 170:278-285

Daly K, Jeffrey D, Tunney H (2001) The effect of soil type on phosphorus sorption capacity and desorption dynamics in Irish grassland soils. Soil Use Manage 17:12-20

Day PR (1965) "Hydrometer method of particle size analysis," in methods of soil analysis. In: Black CA (ed) Agronomy Part I No. 9. American Society of Agronomy, Madison, pp 562-563

Desta HA (2015) Reclamation of phosphorus fixation by organic matter in acidic soils. Glob J Agric Sci 3:271-278

Dodor DE, Oya K (2000) Phosphate sorption characteristics of major soils in Okinawa, Japan. Commun Soil Sci Plant Anal 31:277-288

Duffera M, Robarge WP (1999) Soil characteristics and management effects on phosphorus sorption by highland plateau soils of Ethiopia. Soil Sci Soc Am J 63:1455-1462

Ehlert P, Morel C, Fotyma M, Destain JP (2003) Potential role of phosphate buffering capacity of soils in fertilizer management strategies fitted to environmental goals. J Plant Nutr Soil Sci 166(4):409-415. https://doi. org/10.1002/jpln.200321182

EIAR (Ethiopian Institute of Agricultural Research) (2011) Coordination of national agricultural research system, Ethiopia, English and Amharic Version. EIAR, Addis Ababa

EthioSIS (Ethiopian Soil Information System) (2014) Soil fertility status and fertility recommendation atlas for Tigray regional state, Ethiopia, July 2014. Addis Ababa, Ethiopia

FAO (Food and Agriculture Organization) (1984) Provisional soil map of Ethiopia. Land Use Planning Project. FAO, Addis Ababa

Fox RL (1981) External P requirements of crops. In: Stelly M (ed) Chemistry of the soil environment. American Society of Agronomy, Madison (Special Publication No. 40)

Fox RL, Kamprath EJ (1970) Phosphate sorption isotherms for evaluating the phosphate requirements of soils. Soil Sci Soc Am Proc 34:902-907

Hansen JC, Strawn DG (2003) Kinetics of phosphorus release from manureamended alkaline soil. Soil Sci 168(12):869-879

Hazelton P, Murphy B (2007) Interpreting soil test results: what do all the numbers mean, 2nd edn. CSIRO Publishing, Clayton

Hedley MJ, Stewart JWB, Chauhan BS (1982) Changes in inorganic and organic soil phosphorus fractions induced by cultivation practices and by laboratory incubations. Soil Sci Soc Am J 46:970-976

Henry PC, Smith MF (2003) A single point sorption test for the routine determination of the phosphorus requirement of low to moderate P-fixing soils. S Afr J Plant Soil 20(3):132-140. https://doi.org/10.1080/02571 862.2003.10634922

Ige DV, Akinremi OO, Flaten DN (2005) Environmental index for estimating the risk of phosphorus loss in calcareous soils of Manitoba. J Envt Qual 34:1944-1951

Jackman JM, Jones RC, Yost RS, Babock CJ (1997) Rietveld estimates of mineral percentages to predict phosphorous sorption by selected Hawaiian soils. Soil Sci Soc Am J 61:618-629

Jalali M (2007) Phosphorus status and sorption characteristics of some calcareous soils of Hamadan, western Iran. Environ Geol 53:365-374. https://doi. org/10.1007/s00254-007-0652-7

Jamison VC, Weaver HH, Reed IF (1950) A hammer-driven soil core sampler. Soil Sci 69:487-496

Janardhanan L, Daroup SH (2010) Phosphorous sorption in organic acids in south florida. Soil Sci Soc Am J 74:1597-1606

Jensen A, Jakobsen I (1970) The occurrence of vesicular-arbuscular mycorrhiza in barley and wheat grown in some Danish soils with different fertilizer treatments. Plant Soil 55:403-414

Jesse R, Fink A, Vasconcellos I, Tales T, Vidal B (2016) Iron oxides and organic matter on soil phosphorous availability. Cienc Agrotecnol 40(4):369-379
Jones JB (2003) Agronomic handbook: management of crops, soils, and their fertility. CRCPress LLC, Boca Raton

Juo ARS, Fox RL (1977) Phosphate sorption characteristics of some benchmark soils of West Africa. J Soil Sci 124:370-376

Kiflu A, Sheleme B, Schoenau J (2017) Fractionation and availability of phosphorus in acid soils of Hagereselam, Southern Ethiopia under different rates of lime. Chem Biol Technol Agric 4:21. https://doi.org/10.1186/s4053 8-017-0105-9

Lavkulich LM (1981) Methods manual, pedology laboratory. Department of soil science. University of British Columbia, Vancouver, British Columbia

Lin C, Banin A (2005) Effect of long-term effluent recharge on phosphate sorption by soils in a wastewater reclamation plant. Water Air Soil Pollut 164:257-273

Makris KC, Harris WG, O'Connor GA, El-Shall H (2005) Long-term phosphorus effects on evolving physicochemical properties of iron and aluminum hydroxides. J. Colloid Interf Sci 287:552-560

Mamo T, Haque I (1987) Phosphorus status of some ethiopian soils-I. Sorption characteristics. Plant Soil 102(2):261-266

McKeague JA, Day JH (1966) Dithionite and oxalate extractable Fe and Al as acids in differentiating various classes of soils. Can J Soil Sci 46:13-22

Mehlich A (1984) Mehlich-III soil test extractant: a modification of Mehlich 2. Commun Soil Sci Plant Anal 15:1409-1416

Mehra OP, Jackson ML (1960) Iron oxide removal from soils and clays by a dthionite-citrate system buffered with sodium bicarbonate. Clays Clay Miner 7:317-327

Moazed H, Hoseini Y, Naseri AA, Abbasi F (2010) Determining phosphorus adsorption isotherm in soil and its relation to soil characteristics. J Food Agric Environ 8:1153-1157

Moody PW, Bolland MDA (1999) Cadmium in soils and plants. Dev Plant Soil Sci 85:1-9

Moreira FLM, Mota FOB, Clemente CA, Azevedo BM, Bomfim GV (2006) Phosphorus adsorption in Ceará State soils, Brazil. Rev Ciên Agron 37:7-12

Morel C, Tunney H, Plénet D, Pellerin S (2000) Transfer of phosphate ions between soil and solution: perspectives in soil testing. J Environ Qual 29:50-59. https://doi.org/10.2134/jeq2000.00472425002900010007x

Morris M, Kelly V, Kopicki R, Byerlee D (2007) Fertilizer use in African agriculture: lessons learned and good practice guidelines. World Bank, Washington, DC

Mozaffari M, Sims JT (1994) Phosphorus availability and sorption in an Atlantic coastal plain watershed dominated by animal based agriculture. Soil Sci 157:97-107

Muindi EM, Mrema JP, Semu E, Mtakwa PW, Gachene CK, Njogu MK (2015) Phosphorus adsorption and its relation with soil properties in acid soils of Western Kenya. Int J Plant Soil Sci 4(3):203-211 (Article no. IJPSS.2015.021 ISSN: 2320-7035)

Obura PA (2008) Effects of soil properties on bioavailability of aluminium and phosphorus in selected Kenyan and Brazilian soils. Ph.D. thesis, Purdue University, Indiana

Olsen SR, Sommers LE (1982) Phosphorus. In: Page AL et al (eds) Methods of soil analysis. Part 2, 2nd edn. Agron. Monogr. 9. ASA and SSSA, Madison, pp 403-430

Onweremadu EU, Eshett ET, Osuji GE (2007) Temporal variability of selected heavy metals in automobile soil. Int J Environ Sci Technol 4:35-41

Peinemann N, Nilda MA, Pablo Z, Maria BV (2002) Effect of clay minerals and organic matter on the cation exchange capacity of silt fractions. J Plant Nutr Soil Sci 163(1):47-52. doi:https://doi.org/10.1002/ (sici)1522-2624(200002)163:1<47:AID-JPLN47>3.0.CO;2-A

Rasmussen PE, Allmaras RR, Rohde RR, Roager NC (1980) Crop residue influences on soil carbon and nitrogen in a wheat-fallow system. Soil Sci Soc Am J 44:596-600

Rayment GE, Lyons DJ (2011) 'Method 4b1 pH of 1:5 soil $0.01 \mathrm{M}$ calcium chloride extract-direct (without stirring during measurement),' 'method13A1 oxalate extractable iron, aluminium and silicon'. Method 9B1 bicarbonate extractable P (Colwell P)-manual colour'"method 9J1 phosphate sorption curve-manual colour' in soil chemical methods-Australasia. CSIRO, Publishing, Australia

Rowell DL (1994) Soil science: method and applications. Addison Wesley Longman, London

Saljnikov KE, Funakawa S, Akhmetov K, Kosaki T (2004) Soil organic matter status of Mollisols soil in North Kazakhstan: effects of summer fallow. Soil Biol Biochem 36:1373-1381 
Saljnikov E, Hospodarenko H, Funakawa S, Kosaki T (2005) Effect of fertilization and manure application on nitrogen mineralization potentials in Ukraine. Zemljiste I biljka 54(3):221-230

Saljnikov E, Cakmak D, Kostic L, Maksimovic S (2009) Labile fractions of soil organic carbon in Mollisols from different climatic regions, vol LIII. Agrochimica, Bolzano, p 6

Sánchez-Alcalá I, Campillo MC, Torrent J (2014) Extraction with $0.01 \mathrm{M} \mathrm{CaCl} 2$ underestimates the concentration of phosphorus in the soil solution. Soil Use Manag 30(2):297-302. https://doi.org/10.1111/sum.12116

Sanchez PA, Uehara G (1980) Management considerations for acid soils with high phosphorus fixation capacity. In: Khasawneh FE, Sample EC, Kamprath EJ (eds) The role of phosphorus in agriculture. American Society of Agronomy, Madison, pp 263-310

SAS (Statistical Analysis System) Institute) (2004) SAS/STAT user's guide. Proprietary software version 9.00. SAS Institute, Inc., Cary

Sims JT, Pierzynski GM (2005) Chemistry of phosphorus in soils. In: Tabatabai MA, Sparks DL (eds) Chemical processes in soils, Soil science society of America book series 8. Soil Science Society of America, Madison, pp $151-192$

Tan KH (2000) Environmental Soil Science, 2nd edn. Marcel Dekker Inc., New York

Van der Zee SEATM, Nederlof MM, Van Riemsdijk WH, de Haan FAM (1988) Spatial variability of phosphate adsorption parameters. J Environ Qual 17:682-688

Van Reeuwijk LP (1992) Procedures for soil analysis, 3rd edn. International Soil Reference and Information Center (ISRIC), Wageningen, p 34

Walkley A, Black IA (1934) An examination of the Degtjareff method for determining soil organic matter and a proposed modification of the chromic acid titration method. Soil Sci 37:29-38

Wang XJM, Jackman Yost RS, Linquist BA (2000) Predicting soil phosphorous buffer coefficients using potential sorption site density and soil aggregation. Soil Sci Soc Am J 64:240-246
Wang Y, Shen ZY, Niu JF, Liu RM (2009) Adsorption of phosphorus on sediments from the Three-Gorges Reservoir (China) and the relation with sediment compositions. J Hazard Mater 162:92-98

Watanabe and Olsen (1965) Test of an ascorbic acid method for determining phosphorus in water and $\mathrm{NaHCO}_{3}$ extracts from soil. Soil Sci Soc Am Proc 29:677-678

Wild A (1950) The retention of phosphate by soil. A review. J Soil Sci 1:221-238

Yan X, Wang D, Zhang H, Zhang G, Wei Z (2013) Organic amendments affect phosphorus sorption characteristics in a paddy soil. Agric Ecosyst Environ 175:47-53

Yan JL, Jiang T, Yao Y, Lu S, Wang QL, Wei SQ (2016) Preliminary investigation of phosphorus adsorption onto two types of iron oxide-organic matter complexes. J Environ Sci-China 42:152-162

Yan X, Zongqiang W, Qianqian H, Zhihong L, Jianfu W (2017) Phosphorus fractions and sorption characteristics in a subtropical paddy soil as influenced by fertilizer sources. Geoderma 295:80-85

Yli-Halla M, Hartikainen H, Vaatainen P (2002) Depletion of soil phosphorus as assessed by several indices of phosphorus supplying power. Eur J Soil Sci $53: 431-438$

Yuan TL, Lucas DE (1982) Retention of phosphorus by sandy soils as evaluated by adsorption isotherms. Soil Crop Sci. Soc. Fla Proc 11:197-201

Zhang H, Schroder JL, Fuhrman JK, Basta NT, Storm DE, Payton ME (2005) Path and multiple regression analyses of phosphorus sorption capacity. Soil Sci Soc Am J 69:96-106

Zinabu W (2015) Phosphorus sorption characteristics and external phosphorus requirement of Bulle and Wonago Woreda, Southern Ethiopia. J Biol Agric Healthc. www.iiste.org ISSN 2224-3208 (Paper) ISSN 2225-093X (Online). 5(5)

Zinabu W, Wassie H, Dhyna S (2015) Phosphorus sorption characteristics and external phosphorus requirement of Bulle and Wonago Woreda. Southern Ethiopia. Adv Crop Sci Tech. 3:2

\section{Submit your manuscript to a SpringerOpen ${ }^{\circ}$ journal and benefit from:}

- Convenient online submission

- Rigorous peer review

- Open access: articles freely available online

- High visibility within the field

- Retaining the copyright to your article

Submit your next manuscript at $\boldsymbol{\nabla}$ springeropen.com 